\title{
Identifikasi Bambu pada Daerah Aliran Sungai Tiupupus Kabupaten Lombok Utara
}

\author{
Huzaemah $^{1 *}$, Tri Mulyaningsih ${ }^{1}$, Evy Aryanti $^{1}$ \\ ${ }^{1}$ Program Studi Biologi, Fakultas Matematika dan Ilmu Pengetahuan Alam, Universitas Mataram \\ J1. Majapahit No. 62, Mataram \\ *email: emmabsa26@gmail.com
}

\begin{abstract}
ABSTRAK
Penelitian ini bertujuan untuk mengetahui jenis-jenis bambu, membuat kunci identifikasi, deskripsi, membuat dendogram hubungan kekerabatan antar jenis bambu, peta persebaran bambu di Daerah Aliran Sungai Tiupupus Lombok Utara dan persebaran jenis-jenis bambu pada tiap ketinggian. Penelitian dilakukan dengan menggunakan metode jelajah, yakni kolektor menjelajahi Daerah Aliran Sungai untuk mengoleksi semua jenis bambu yang ada di sepanjang sungai utama (6.576 meter), 50 meter dari tepi kiri dan kanan palung sungai. Hasil penelitian didapatkan 9 jenis dan 1 varietas yang termasuk ke dalam anggota dari 5 marga yaitu Dendrocalamus asper, Thyrsostachys siamensis, Schizostachyum jaculans, Gigantochloa atter, Gigantochloa apus, Bambusa glaucophylla, Bambusa multiplex, Bambusa maculata, Bambusa vulgaris, dan Bambusa vulgaris var. vittata.
\end{abstract}

Kata Kunci: Keanekaragaman Bambu, Sungai Tiupupus Lombok Utara 


\section{Pendahuluan}

Bambu adalah tanaman yang termasuk suku Poaceae (rumput-rumputan) (Wong, 2004). Bambu merupakan sumber daya yang sangat melimpah dan memiliki keanekaragaman yang cukup tinggi (Paembonan, 2001). Menurut Widjaja dan Karsono (2005), di Indonesia diduga terdapat 157 jenis bambu. Jumlah ini merupakan lebih dari $10 \%$ jenis bambu dunia, 50\% merupakan jenis bambu yang telah dimanfaatkan oleh penduduk dan sangat berpotensi untuk dikembangkan bagi ekonomi masyarakat, baik untuk keperluan sehari-hari, seperti pipa air, alat penangkap ikan maupun untuk membuat mebel yang dapat dijual.

Tanaman bambu dari segi ekologis memiliki kemampuan menjaga keseimbangan lingkungan karena sistem perakarannya dapat mencegah erosi dan mengatur tata air (Sukawi, 2010). Sifat tersebut menjadikan bambu sesuai sebagai tanaman konservasi Daerah Aliran Sungai (DAS) dan menjaga stabilitas lahan pertanian sawah yang berada di sekitar atau pinggiran sungai terhadap erosi lahan (Sjah, 2007).

Berdasarkan Permen PUPR Nomor 04/PRT/M/2015 tanggal 18 Maret 2015, tentang Kriteria dan Penetapan Wilayah Sungai, Provinsi Nusa Tenggara Barat di bagi menjadi 2 Wilayah Sungai (WS), yaitu WS Lombok dan WS Sumbawa. DAS Tiupupus secara administratif berada di Kabupaten Lombok Utara dengan panjang sungai utama 6.576 meter.

Berdasarkan uraian di atas, penting dilakukan penelitian untuk mengidentifikasi bambu di DAS Tiupupus Lombok Utara mengingat bahwa daerah ini merupakan daerah persebaran bambu dan daerah yang memiliki jenis bervariasi.

Penelitian ini bertujuan untuk mengetahui jenis-jenis bambu, membuat kunci identifikasi, deskripsi, membuat dendogram hubungan kekerabatan antar jenis bambu, peta persebaran bambu di DAS Tiupupus Lombok Utara dan persebaran jenis-jenis bambu pada tiap ketinggian.

\section{Bahan dan Metode}

Penelitian ini dilaksanakan di DAS Tiupupus Kabupaten Lombok Utara dan Laboratorium Biologi FMIPA Universitas Mataram dari bulan Januari sampai dengan Mei 2016.Alat-alat yang akan digunakan dalam penelitian ini antara lain alat tulis, buku identifikasi, kamera, GPS, etiket, haga meter, termohigrometer, jangka sorong, lup, handy counter, karung, cutter, roll meter, parang, sasak, tali rafia, oven, kompas, sepatu boot. Bahan-bahan yang digunakan adalah kantong plastik, kertas CD, kertas koran, kertas label, selotip, lem, alkohol $70 \%$, sampel bambu, color chart untuk tumbuhan (Munsell, 1972).

Penelitian dilakukan dengan menggunakan metode jelajah, yakni kolektor menjelajahi DAS untuk mengoleksi semua jenis bambu yang ada di sepanjang DAS Tiupupus Lombok Utara, yakni hingga 50 meter dari tepi kiri dan kanan palung sungai berdasarkan pada Peraturan Pemerintah Republik Indonesia Nomor 38 Tahun 2011 mengenai Sungai. Data masing-masing jenis bambu dicatat dalam tabel karakteristik yang sudah disediakan. Selanjutnya diambil tiga spesimen dari masing-masing jenis, bagian yang diambil antara lain: rebung, daun, 
percabangan, pelepah, dan organ reproduksi. Pada setiap lokasi pengambilan sampel direkam posisi koordinatnya dengan menggunakan GPS.

Spesimen yang diperoleh disemprot menggunakan alkohol $70 \%$ lalu di atur diantara lembaran koran dan dimasukkan ke dalam sasak untuk dioven minimal selama 3 hari dengan suhu $50{ }^{0} \mathrm{C}$. Setelah kering spesimen di tempel pada kertas, diberi etiket untuk selanjutnya siap diidentifikasi dan disimpan. Spesimen yang terkumpul diidentifikasi menggunakan diskriptor, yaitu buku pustaka: Orders and Families of Malayan Seed Plants (Keng, H., 1969), Taxonomy of Vascular Plants (Lawrence, G.H.M., 1951), Vascular Plants Systematics (Radford, A.E., et al. 1974), Identikit Jenis-Jenis Bambu di Kepulauan Sunda Kecil (Widjaja, E.A., 2001); Bio-Diversity Professional version 2 (1997), dan URL plantlist. Data disajikan dalam bentuk kunci identifikasi, dendogram, deskripsi, peta persebaran, dan gambar jenis-jenis bambu di DAS Tiupupus Lombok Utara.

\section{Hasil dan Pembahasan}

\subsection{Kunci identifikasi jenis-jenis bambu}

\section{Daerah Aliran Sungai Tiupupus Lombok Utara}

1. a. Tinggi pohon $>15 \mathrm{~m}$, diameter batang $>10 \mathrm{~cm}$, akar udara muncul hingga buku ke 10, pelepah batang memiliki 2 tipe trikoma: berbulu kempa (tomentose) yang tersebar di seluruh permukaan luar pelepah batang dan menyutera (sericeous) di pinggir permukaan luar pelepah batang........................... asper

b.Tinggi pohon $<15 \mathrm{~m}$, diameter $<10$ $\mathrm{cm}$, akar udara tumbuh di bawah buku ke 5, pelepah batang memiliki 1 tipe trikoma...............................2

2. a.Panjang ruas batang $>50 \mathrm{~cm}$, seluruh buku batang coklat diapit garis putih, permukaan pelepah batang berbulu balig halus (puberulent), ligula berbulu kejur, cabang sama besar, memiliki $>20$ cabang dalam satu berkas percabangan, pangkal daun sadak (oblique).................... jaculans

b.Panjang ruas batang $<50 \mathrm{~cm}$, buku batang coklat polos atau kadang diapit garis putih, permukaan pelepah batang menyutera, ligula gundul, satu cabang lebih besar dari cabang lainnya, memiliki <20 cabang dalam satu berkas percabangan, pangkal daun tumpul (obtusus)............................3

3. a.Warna pelepah rebung hijau muda dengan bagian tengah keunguan, trikoma pelepah rebung dan trikoma pelepah batang berwarna putih, bentuk pelepah batang segitiga sama kaki menyempit (narrowly triangular) T. siamensis

b. Warna pelepah rebung hijau atau hijau muda bergaris kuning, trikoma pelepah rebung dan trikoma pelepah batang berwarna coklat atau coklat kehitaman, bentuk pelepah batang mendelta, segitiga sama kaki melebar (widely triangular) atau segitiga sama kaki (triangular)........................4

4. a. Arah pertumbuhan rebung berlawanan arah jarum jam, permukaan ruas batang menyutera tebal tersebar di seluruh permukaan ruas batang, posisi daun pelepah batang terlekuk balik, pangkal batang lurus..................5 
b. Arah pertumbuhan rebung searah jarum jam, permukaan ruas batang gundul mengkilat kecuali di sekitar buku batang menyutera jarang, posisi daun pelepah tegak, pangkal batang bengkok....................................6

5. a. Warna trikoma pelepah rebung dan trikoma pelepah batang coklat, buku batang coklat kadang diapit garis putih............................. atter

b. Warna trikoma pelepah rebung dan trikoma pelepah batang coklat kehitaman, buku batang coklat polos.............................. apus

6.a. Tinggi pohon 1-10 $\mathrm{m}$, tidak memiliki akar udara, pangkal pelepah rebung menyutera, susunan pelepah rebung tidak rapat .............................

b. Tinggi pohon $10-15 \mathrm{~m}$, memiliki akar udara, pangkal pelepah rebung membludru (velutinous), susunan pelepah rebung rapat................... 8

7.a.Warna ruas batang hijau, pelepah batang memiliki auricula (cuping), daun hijau bergaris putih B. glaucophylla

b. Warna ruas batang kuning garis hijau, pelepah batang tidak memiliki auricula, daun hijau polos....... B. multiplex

8.a.Warna pelepah rebung hijau muda bergaris kuning, ruas batang hidup hijau totol-totol coklat, bentuk pelepah batang segitiga sama kaki melebar, bagian dalam daun pelepah batang berbulu kempa jarang dan tidak membentuk pola.................. maculata

b.Warna pelepah rebung hijau, ruas batang hijau atau hijau bergaris kuning, bentuk pelepah batang mendelta, bagian dalam daun pelepah batang berbulu kempa tebal dan membentuk pola garis vertikal sejajar...............9

9.a.Warna ruas batang hijau polos............................ vulgaris

b.Warna ruas batang kuning garis hijau................ vulgaris var. vitata

\subsection{Dendogram Hubungan Kekerabatan Antar Jenis Bambu Daerah Aliran Sungai Tiupupus Lombok Utara

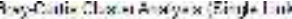

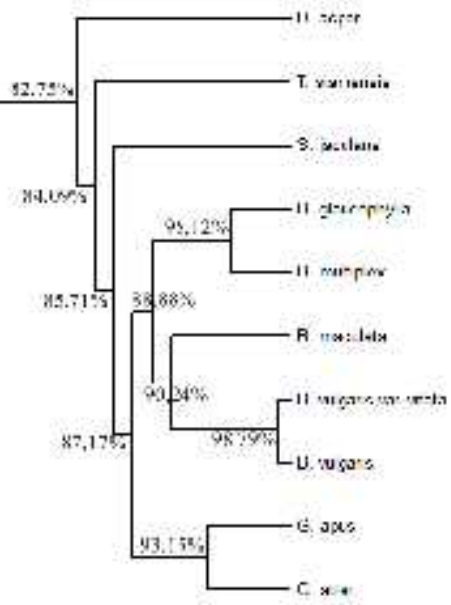


Gambar 1. Dendogram hubungan kekerabatan antar jenis bambu di Daerah Aliran Sungai Tiupupus Lombok Utara

Perhitungan hasil kemiripan atau indeks similaritas dilakukan dengan menggunakan softwear BioDiversity professional version 2 (1997). Adapun tahapan analisa hubungan kekerabatan sebagai berikut: (1) skoring hasil pengamatan 28 karakter, (2) memasukkan data skoring ke dalam softwear BioDiversity professional version 2 (1997). Hasil pengukuran kemiripan diperoleh dalam bentuk dendrogram diatas. Nilai similaritas terendah terdapat pada hubungan kekerabatan antara $D$. asper dengan $G$. atter, B. vulgaris, $T$. siamensis, $B$. multiplex, B. vulgaris var. vitata, B. glaucophylla, G. apus, B. maculata, dan $S$. jaculans sebesar 82,75\% dengan variasi karakter berbeda yaitu tinggi pohon, akar

\subsection{Deskripsi}

1. Dendrocalamus asper (Schult.) Bac-ker: Nutt. Pl. Ned.-Ind. ed. 2, 1: 3011927.

Tinggi pohon 17-19 m, akar rimpang bertipe pakimorf, akar udara tumbuh sampai buku ke 10. Rebung pelepah rebung coklat muda (6/4 2.5 Y), menyutera coklat kehitaman (3/1 2.5 Y). Ruas batang berwarna hijau keabuan (5/4 2.5 G), panjang $\mathrm{x}$ diameter ruas batang $35-37,50 \mathrm{~cm} \times 10,39$ $12,12 \mathrm{~cm}$. Pelepah batang segitiga sama kaki melebar, berbulu kempa krem (8/4 5 Y) tersebar di seluruh permukaan luar pelepah batang dan menyutera coklat (4/3 2.5 Y) di pinggir permukaan luar pelepah batang, daun pelepah batang segitiga sama kaki menyempit; tinggi cuping 0,50-0,70 cm dengan panjang bulu kejur 0,30-0,50 cm; udara, warna pelepah rebung, diameter ruas batang, dan tipe trikoma pelepah batang. Nilai similaritas tertinggi terdapat pada hubungan kekerabatan antara $B$. vulgaris dan B. vulgaris var. vitata sebesar 98,79\% dengan karakter berbeda yaitu warna ruas batang.

Sokal dan Sneath (1963) menyatakan bahwa semakin banyak persamaan karakter yang dimiliki maka semakin banyak besar nilai similaritasnya berarti semakin dekat hubungan kekerabatan diantara jenis yang diperbandingkan. Sebaliknya semakin banyak perbedaan karakter yang dimiliki maka semakin kecil nilai similaritasnya berarti semakin jauh hubungan kekerabatan diantara jenis yang diperbandingkan.

ligula berbulu kejur 0,10-0,20 cm. Pelepah daun berbulu balig halus coklat (6/3 10 YR), alas $\mathrm{x}$ tinggi pelepah daun $0,9-1,20 \mathrm{~cm} \mathrm{x}$ 8,40-9,50 cm; cuping dan ligula pelepah daun berbulu kejur. Tangkai daun gundul, panjang $\mathrm{x}$ diameter $0,90-1,20 \mathrm{~cm} \times 0,12$ $0,15 \mathrm{~cm}$. Daun hijau (6/6 $5 \mathrm{GY})$, permukaan daun abaksial gundul, permukaan daun adaksial menyutera putih tersebar di seluruh helaian daun, panjang $\mathrm{x}$ lebar helaian daun $36-41,20 \mathrm{~cm} \times 3,90-5,60 \mathrm{~cm}$.

Distribusi: Kabupaten Lombok Utara Kecamatan Gangga, Desa Genggelang:

\section{Kerta.}

Dusun Karang jurang, Kerurak,

Nama lokal: Petung (Sasak Bayan). 


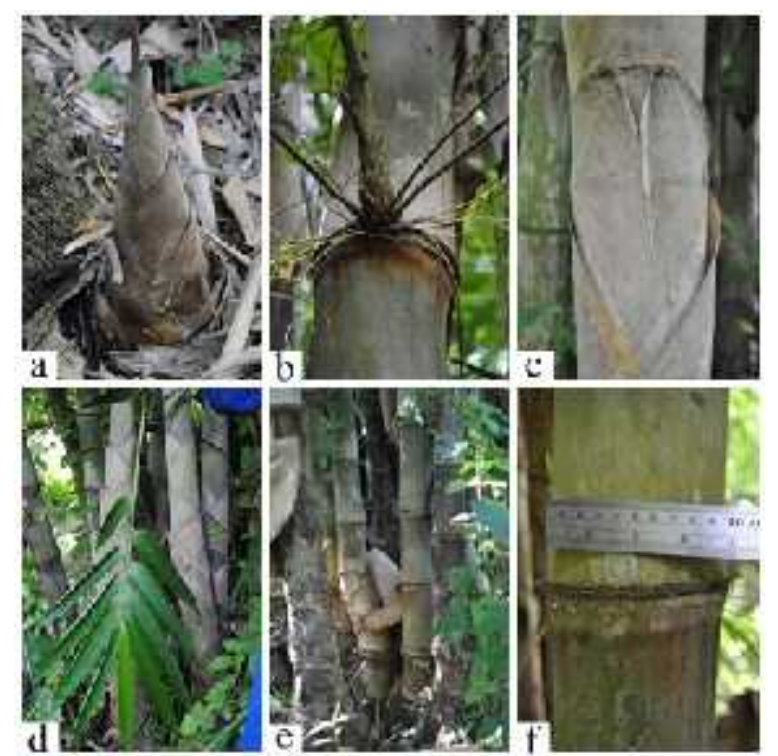

Gambar 2. D. asper: (a). rebung, (b). percabangan, (c). pelepah batang, (d). daun, (e). pangkal batang, (f). buku batang

2. Thyrsostachys siamensis Gamble: Ann. Roy. Bot. Gard. (Calcutta) 7: 591896.

Tinggi pohon 8-9 $\mathrm{m}$, akar rimpang bertipe pakimorf, tidak memiliki akar udara. Pelepah rebung hijau muda dengan bagian tengah keunguan (5/4 7.5 GY), menyutera putih jarang dan tersebar di seluruh pelepah rebung, susunan pelepah rebung tidak rapat, arah pertumbuhan rebung searah jarum jam. Ruas batang berwarna hijau (4/8 5 GY), menyutera putih, panjang $\mathrm{x}$ diameter ruas batang 22-24,50 cm x 3,98-4,15 cm. Pelepah batang segitiga sama kaki menyempit, menyutera putih, daun pelepah batang segitiga sama kaki, tidak memiliki cuping; ligula gundul.

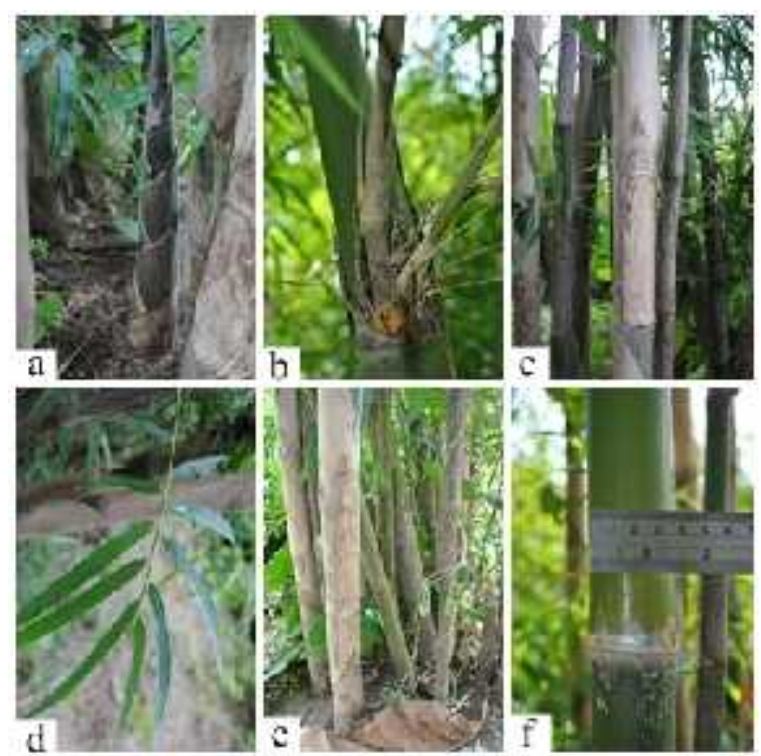

Gambar 3. T. siamensis: (a). rebung, (b). percabangan, (c). pelepah batang, (d). daun, (e). pangkal batang, (f). buku batang

Percabangan satu cabang lebih besar dari cabang lainnya, berkas cabang tersusun atas 5-6 cabang. Pelepah daun gundul, alas $\mathrm{x}$ tinggi pelepah daun 0,30-0,40 $\mathrm{cm} \times 4-4,50$ $\mathrm{cm}$, tidak memiliki cuping; ligula gundul. Tangkai daun gundul, panjang $\mathrm{x}$ diameter $0,10 \mathrm{~cm}$ x 0,05 cm. Daun hijau (6/6 5 GY), gundul, panjang $x$ lebar helaian daun 17,50$19,30 \mathrm{~cm} \times 1-1,20 \mathrm{~cm}$, pangkal daun tumpul.

Distribusi: Kabupaten Lombok Utara, Kecamatan Gangga, Desa Genggelang, Dusun Jeliti.

Nama lokal: Santong hias cina (Sasak Bayan).

3. Schizostachyum jaculans Holttum: Kew Bull. 8: 4941953 publ. 1954.

Tinggi pohon 11-12 m, akar rimpang bertipe pakimorf, tidak memiliki akar udara. Panjang x diameter ruas batang 67-98 cm x 1,78-1,92 cm, buku batang coklat muda $(5 / 6$ $2.5 \mathrm{Y})$ diapit garis putih. 


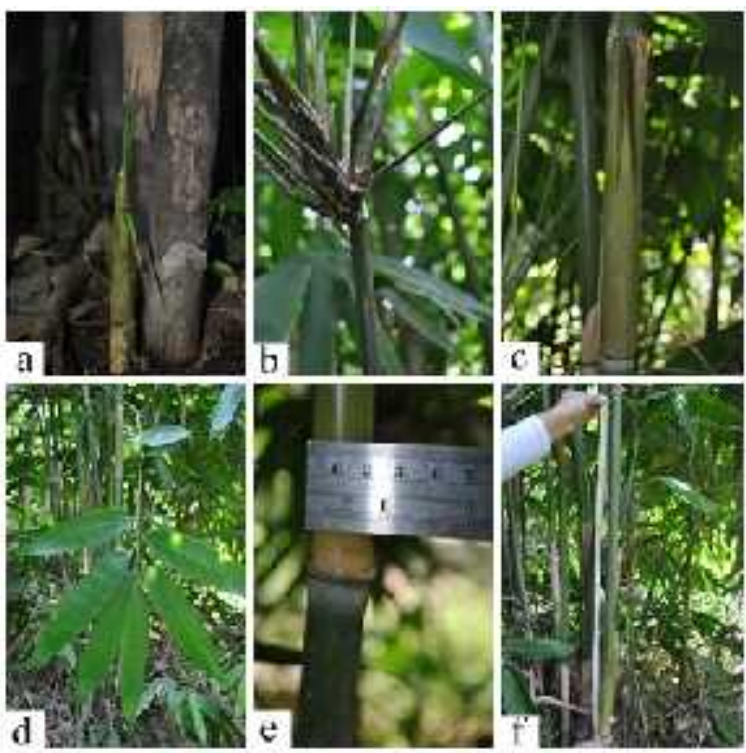

Gambar 4. S. jaculans: (a). rebung, (b). percabangan, (c). pelepah batang, (d). daun, (e). buku batang, (f). ruas batang

Pelepah batang segitiga sama kaki, berbulu balig halus (puberulent) coklat muda (5/4 $2.5 \mathrm{Y}$ ), daun pelepah batang segitiga sama kaki menyempit, tinggi cuping 0,10-0,20 cm; ligula berbulu kejur dengan panjang bulu kejur 1-1,30 $\mathrm{cm}$. Percabangan cabang sama besar, berkas cabang tersusun atas 2226 cabang. Pelepah daun berbulu balig halus coklat (6/3 10 YR), ligula berbulu kejur dengan panjang bulu kejur 0,50-0,60 cm, alas $\mathrm{x}$ tinggi pelepah daun 1,20-1,50 cm x 9$11 \mathrm{~cm}$. Tangkai daun gundul, panjang $\mathrm{x}$ diameter 0,80-1 cm x 0,10-0,14 cm. Daun hijau (6/6 $5 \mathrm{GY})$, permukaan daun abaksial gundul, permukaan daun adaksial menyutera putih tersebar di seluruh helaian daun, panjang x lebar helaian daun 29-31,50 cm x 4,70-5,30 cm, pangkal daun sadak (oblique).

Distribusi: Kabupaten Lombok Utara, Kecamatan Gangga, Desa Genggelang: Dusun Karang jurang, Kerurak, Kerta.

Nama lokal: Bilok (Sasak Bayan).
4. Gigantochloa atter (Hassk.) Kurz: Natuurk. Tijdschr. Ned.-Indië 27: 2261864. Tinggi pohon 13-15 m, akar rimpang bertipe pakimorf, memiliki akar udara yang tumbuh sampai buku ke 2. Pelepah rebung hijau muda (7/10 $5 \mathrm{GY})$, menyutera coklat muda (6/4 2.5 Y), susunan pelepah rebung rapat, arah pertumbuhan rebung berlawanan arah jarum jam. Ruas batang berwarna hijau muda (6/6 7.5 GY), menyutera coklat muda (6/4 2.5 Y) tebal dan tersebar di seluruh ruas batang, panjang $\mathrm{x}$ diameter ruas batang 40$47 \mathrm{~cm} \times 6,23-6,47 \mathrm{~cm}$, buku batang coklat muda (4/4 2.5 Y) kadang diapit garis putih melingkar, pangkal batang lurus. Pelepah batang segitiga sama kaki melebar, menyutera coklat muda (6/4 2.5 Y), daun pelepah batang segitiga sama kaki melebar, posisi daun pelepah batang terlekuk balik, tinggi cuping 0,40-0,50 cm dengan panjang bulu kejur 0,20-0,30 cm; ligula berbulu kejur 0,10-0,15 cm. Percabangan satu cabang lebih besar dari cabang lainnya, berkas cabang tersusun atas 6-10 cabang. Pelepah daun menyutera coklat muda (5/6 2.5 YR), alas $\mathrm{x}$ tinggi pelepah daun 1,40-1,60 $\mathrm{cm} \mathrm{x}$ 6,8-8 cm; cuping dan ligula pelepah daun berbulu kejur. Tangkai daun gundul, panjang $\mathrm{x}$ diameter $0,40-0,70 \mathrm{~cm} \times 0,11$ $0,13 \mathrm{~cm}$. Daun hijau (6/6 $5 \mathrm{GY})$, permukaan daun abaksial dan adaksial gundul, panjang x lebar helaian daun 34-39,50 cm x 4,50$5,40 \mathrm{~cm}$, pangkal daun tumpul. Distribusi: Kabupaten Lombok Utara, Kecamatan Gangga, Desa Genggelang: Dusun Karang jurang, Lokok bengkok, Gondang timuq, Sembaro, Jeliti, Kerurak, Penjor, Kerta, Gangga, Lias; Desa Bentek: Dusun Kakong dan Dusun Batu ringgit.

Nama lokal: Santong biasa (Sasak 
Bayan).

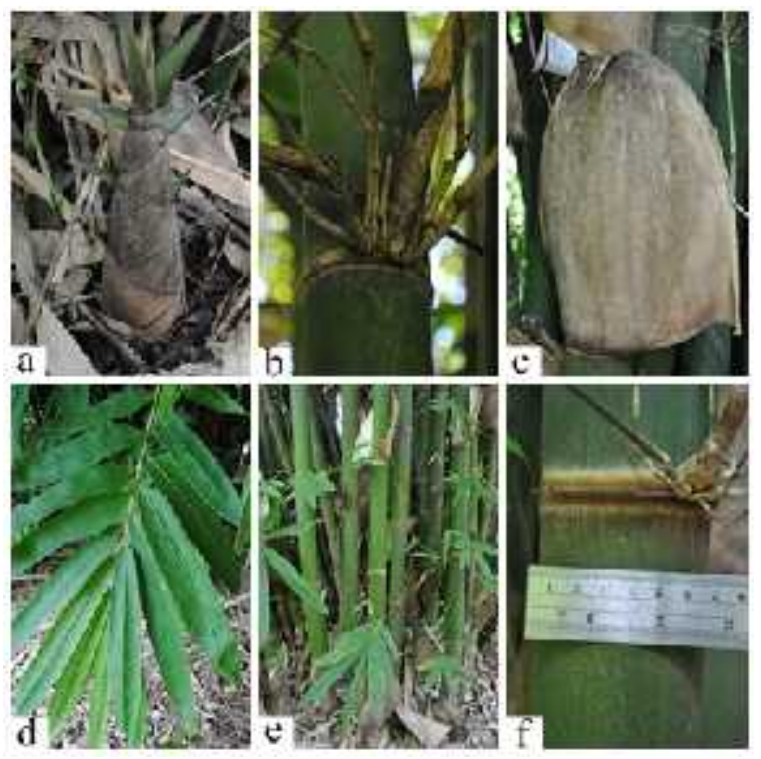

Gambar 5. G. atter: (a). rebung, (b). percabangan, (c). pelepah batang, (d). daun, (e). pangkal batang, (f). buku batang

5. Gigantochloa apus (Schult.) Kurz: Natuurk. Tijdschr. Ned.-Indië 27: 2261864.

Tinggi pohon 13-15 m, akar rimpang bertipe pakimorf, akar udara tumbuh sampai buku ke 2. Pelepah rebung hijau muda (6/6 5 GY), menyutera cokelat kehitaman (3/1 $2.5 \mathrm{Y})$, susunan pelepah rebung rapat, arah pertumbuhan rebung berlawanan arah jarum jam. Ruas batang hijau keabuan (6/4 7.5 GY), menyutera coklat kehitaman (3/1 $2.5 \mathrm{Y})$ tebal dan tersebar di seluruh ruas batang, panjang $\mathrm{x}$ diameter ruas batang $36-39 \mathrm{~cm} \times 5,56-7,16$ $\mathrm{cm}$, buku batang berwarna coklat tua polos (4/4 2.5 Y), pangkal batang lurus. Pelepah batang segitiga sama kaki melebar, menyutera coklat kehitaman ( $3 / 1 \quad 2.5 \mathrm{Y})$, daun pelepah batang segitiga sama kaki melebar, posisi daun pelepah batang terlekuk balik, tinggi cuping 0,30-0,50 $\mathrm{cm}$ dengan panjang bulu kejur 0,20-0,30 cm; ligula berbulu kejur $0,10-0,20 \mathrm{~cm}$. Percabangan satu cabang lebih besar dari cabang lainnya, berkas cabang tersusun atas 7-9 cabang. Pelepah daun menyutera coklat muda (6/3 10 YR); cuping dan ligula pelepah daun berbulu kejur. Daun hijau (5/6 5 GY), gundul, panjang $\mathrm{x}$ lebar helaian daun 31$35,60 \mathrm{~cm} \times 6-6,50 \mathrm{~cm}$, pangkal daun tumpul.

Distribusi: Kabupaten Lombok Utara, Kecamatan Gangga, Desa Genggelang: Dusun Karang jurang, Lokok bengkok, Gondang timuq, Sembaro, Jeliti, Kerurak, Penjor, Kerta, Gangga, Lias; Desa Bentek, Dusun Kakong.

Nama lokal: Tereng (Sasak Bayan).

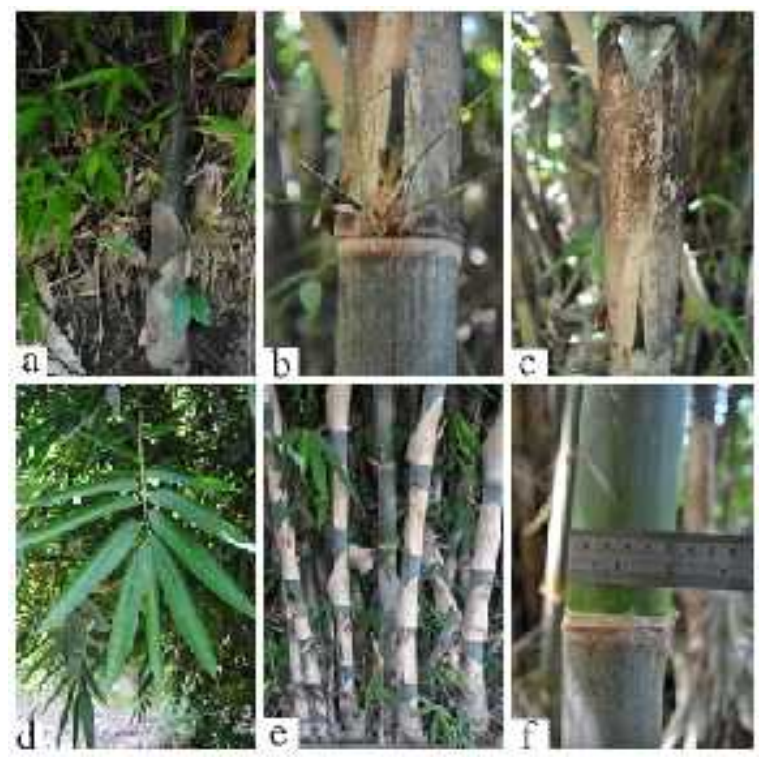

Gambar 6. G. apus: (a). rebung, (b). percabangan, (c). pelepah batang, (d). daun, (e). pangkal batang, (f). buku batang

6. Bambusa multiplex (Lour.) Raeusch. ex Schult.: Syst. Veg. 7: 13501830.

Tinggi pohon 1,5-2,5 m, akar rimpang bertipe pakimorf, tidak memiliki akar udara. Ruas batang berwarna kuning bergaris hijau muda (6/10 5 GY), gundul mengkilat kecuali di sekitar buku batang berbulu kempa coklat (4/3 2.5 Y), panjang x diameter ruas batang $21-23 \mathrm{~cm} \times 0,75-0,84$ 
$\mathrm{cm}$, pangkal batang bengkok. Pelepah batang segitiga sama kaki (triangular), menyutera coklat muda (5/4 $2.5 \mathrm{Y})$, daun pelepah batang segitiga sama kaki menyempit, posisi daun pelepah batang tegak, tidak memiliki cuping, ligula gundul.

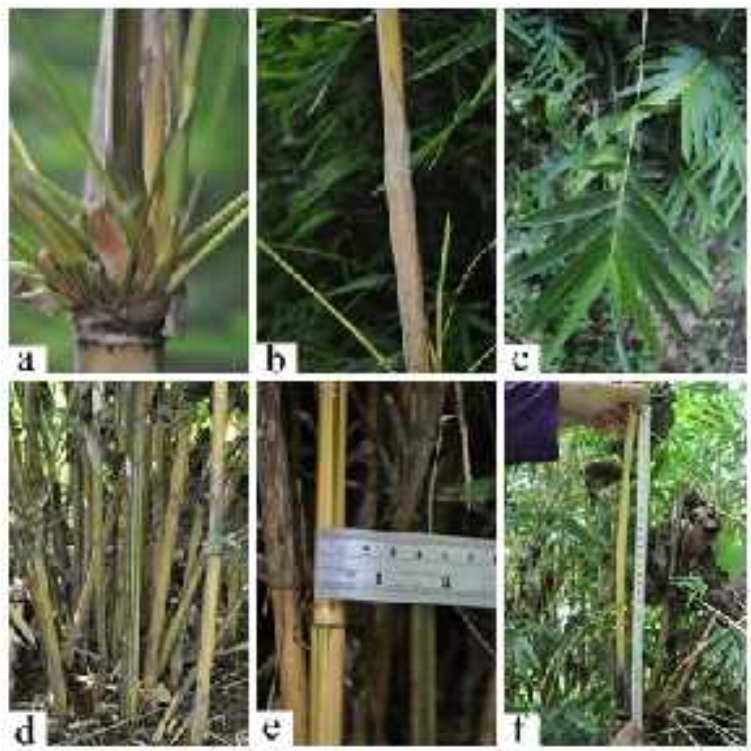

Gambar 7. B. multiplex: (a). percabangan, (b). pelepah batang, (c). daun, (d). pangkal batang, (e). diameter batang, (f). ruas batang

Percabangan satu cabang lebih besar dari cabang lainnya, berkas cabang tersusun atas 10 cabang. Pelepah daun berbulu kempa coklat muda (5/4 $2.5 \mathrm{Y})$, tidak memiliki cuping, ligula gundul. Daun hijau muda polos (6/6 $5 \mathrm{GY})$, gundul, panjang x lebar helaian daun 10-11,80 $\mathrm{cm} \times 1,20-1,70 \mathrm{~cm}$, pangkal daun tumpul.

Distribusi: Kabupaten Lombok Utara, Kecamatan Gangga, Desa Bentek, Dusun Kakong.

Nama lokal: Santong hias cina kuning (Sasak Bayan).

7. Bambusa glaucophylla Widjaja: Reinwardtia 11: 591997.

Tinggi pohon 1,5-2 m, akar rimpang bertipe pakimorf, tidak memiliki akar udara. Pelepah rebung berwarna hijau muda (7/10 5 GY), menyutera coklat tua $\left(\begin{array}{llll}4 / 4 & 2.5 & \mathrm{Y}\end{array}\right)$ jarang dan tersebar, pangkal pelepah rebung menyutera, susunan pelepah rebung tidak rapat, arah pertumbuhan rebung searah jarum jam.

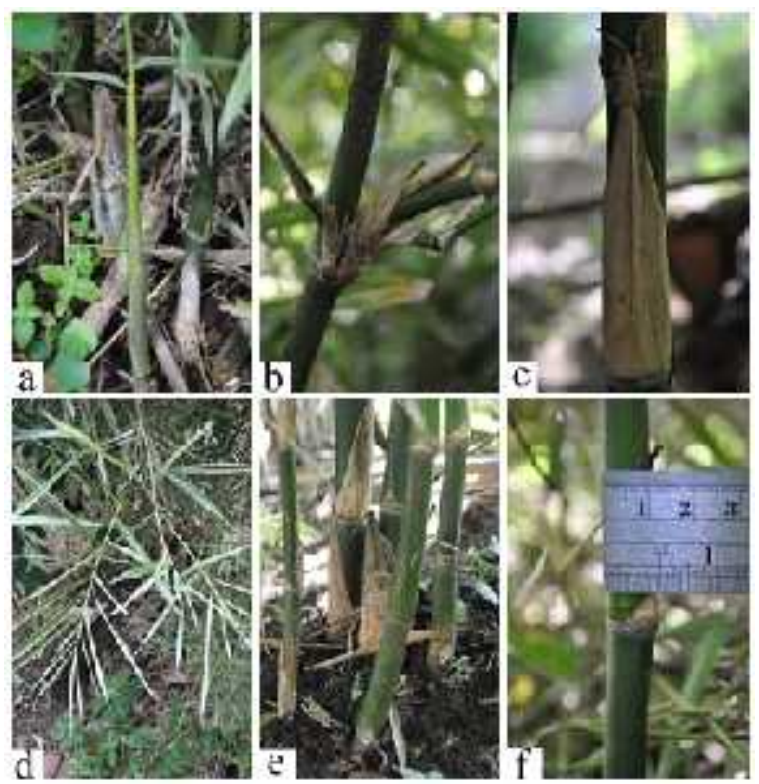

Gambar 8. B. glaucophylla: (a). rebung, (b). percabangan, (c). pelepah batang, (d). daun, (e). pangkal batang, (f). buku batang

Ruas batang berwarna hijau tua (4/8 $5 \mathrm{GY})$, gundul mengkilat kecuali di sekitar buku batang berbulu kempa coklat tua (4/3 2.5 Y) jarang, panjang $\mathrm{x}$ diameter ruas batang 8,50-10 cm x 1,06-1,18 cm, pangkal batang bengkok. Pelepah batang segitiga sama kaki melebar, menyutera coklat muda (5/4 2.5 Y), posisi daun pelepah batang tegak, tinggi cuping 0,20-0,30 $\mathrm{cm}$ dengan panjang bulu kejur 0,20-0,30 cm, ligula gundul. Percabangan satu cabang lebih besar dari cabang lainnya, berkas cabang tersusun atas 5 cabang. Pelepah daun berbulu kempa coklat muda (6/4 2.5 Y), daun pelepah batang segitiga sama kaki. Daun hijau muda (6/6 5 
GY) bergaris putih, gundul, panjang $\mathrm{x}$ lebar helaian daun $15-17,50 \mathrm{~cm} \times 1,10-1,40 \mathrm{~cm}$, menggulung seperti layu, pangkal daun tumpul.

Distribusi: Kabupaten Lombok Utara, Kecamatan Gangga, Desa Genggelang, Dusun Kerurak.

Nama lokal: Santong hias (Sasak Bayan).

\section{Bambusa maculata Widjaja: Reinwardtia} 11: 631997.

Tinggi pohon 11-14 $\mathrm{m}$, akar rimpang bertipe pakimorf, akar adventif tumbuh sampai buku ke 3. Pelepah rebung hijau muda $(7 / 85 \mathrm{GY})$ bergaris kuning, menyutera coklat (4/3 2.5 Y), pangkal pelepah rebung berjonjot coklat muda $(5 / 32.5 \mathrm{Y})$, susunan pelepah rebung rapat, arah pertumbuhan rebung searah jarum jam. Ruas batang hijau tua (4/6 $5 \mathrm{GY}$ ) totol-totol coklat tua (3/1 10YR), gundul mengkilat kecuali sekitar buku batang berbulu kempa coklat (5/4 2.5 Y) jarang, panjang x diameter ruas batang 30-39 $\mathrm{cm} \times 6,26-6,89 \mathrm{~cm}$, pangkal batang bengkok. Pelepah batang segitiga sama kaki melebar, menyutera coklat (4/3 $2.5 \mathrm{Y}$ ), bagian dalam daun pelepah batang berbulu kempa jarang dan tidak membentuk pola, daun pelepah batang segitiga sama kaki melebar, posisi daun pelepah batang tegak, tinggi cuping 0,90-1 cm dengan panjang bulu kejur 1-1,20 cm; ligula gundul. Percabangan satu cabang lebih besar dari cabang lainnya, berkas cabang tersusun atas 6-10 cabang. Pelepah daun berbulu kempa coklat muda (5/3 $2.5 \mathrm{Y})$; cuping berbulu kejur; ligula gundul. Daun hijau (4/6 5 GY), gundul, panjang x lebar helaian daun 26,30$34,50 \mathrm{~cm} \times 4-4,40 \mathrm{~cm}$, pangkal daun tumpul.
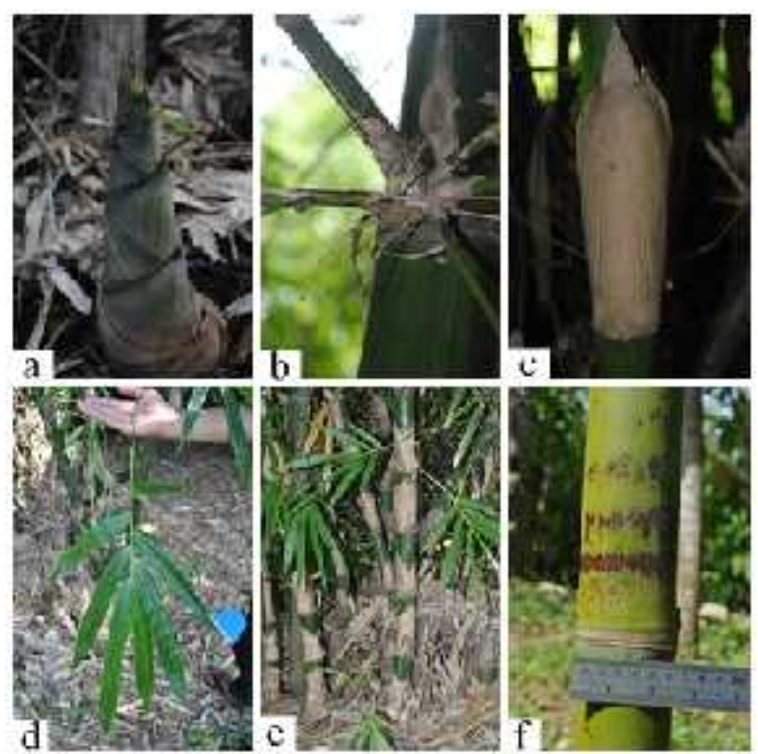

Gambar 9. B. maculata: (a). rebung, (b). percabangan, (c). pelepah batang, (d). daun, (e). pangkal batang, (f). buku batang

Distribusi: Kabupaten Lombok Utara, Kecamatan Gangga, Desa Ganggelang: Dusun Karang jurang, Lokok bengkok, Dusun Gondang timuq, Dusun Sembaro, Jeliti, Kerurak, Penjor, Kerta, Gangga, Lias.

Nama lokal: Tutul (Sasak Bayan).

9. Bambusa vulgaris Schrad.: Coll. Pl. 2: 26 1808.

Tinggi pohon 12-15 m, akar rimpang bertipe pakimorf, memiliki akar udara yang tumbuh sampai buku ke 4. Pelepah rebung hijau (6/10 $5 \mathrm{GY})$, menyutera coklat kehitaman (3/2 2.5 Y), pangkal pelepah rebung membeludru, susunan pelepah rebung rapat, arah pertumbuhan rebung searah jarum jam. Ruas batang berwarna hijau tua polos (5/6 $7.5 \mathrm{GY})$, gundul mengkilat kecuali di sekitar buku batang berbulu kempa coklat tua (4/3 2.5 Y) jarang, panjang $x$ diameter ruas batang $32-35 \mathrm{~cm} \mathrm{x}$ $6,62-7,42 \mathrm{~cm}$, pangkal batang bengkok. 
Pelepah batang mendelta, menyutera coklat kehitaman (3/2 2.5 Y), daun pelepah batang mendelta, bagian dalam daun pelepah batang berbulu kempa tebal dan membentuk pola garis vertikal sejajar, posisi daun pelepah batang tegak, tinggi cuping 1-1,50 cm dengan bulu kejur 1-1,10 cm, ligula berbulu kejur 0,2-0,30 cm pada tepinya. Percabangan satu cabang lebih besar dari cabang lainnya dengan jumlah cabang 5-6 cabang dalam satu berkas percabangan. Pelepah daun berbulu kempa coklat (4/4 2.5 Y), cuping berbulu kejur; ligula berbulu kejur pada tepinya. Daun hijau (4/8 5 GY), gundul, panjang x lebar helaian daun 20-27 $\mathrm{cm} \times 3,10-3,90 \mathrm{~cm}$, pangkal daun tumpul.

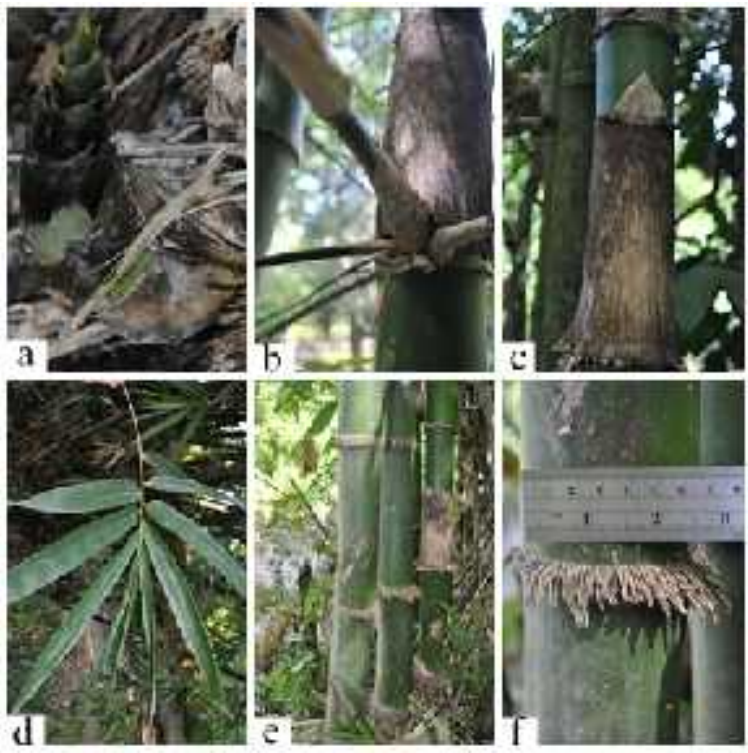

Gambar 10. B. vulgaris: (a). rebung, (b). percabangan, (c). pelepah batang, (d). daun, (e). pangkal batang, (f). akar udara ruas ke-4

Distribusi: Kabupaten Lombok Utara, Kecamatan Gangga, Desa Genggelang: Dusun Karang jurang, Lokok bengkok, Gondang timuq, Sembaro, Jeliti, Kerurak, Penjor, Kerta, Gangga, Lias; Desa Bentek: Dusun Kakong dan Dusun Batu ringgit.

Nama lokal: Aur (Sasak Bayan).

10. Bambusa vulgaris Schrad var. vittata Rivière \& C.Rivière: Bull. Soc. Natl. Acclim. France III, 5: 6401878.

Tinggi pohon 11-12 m, akar rimpang bertipe pakimorf, memiliki akar udara yang tumbuh sampai buku ke 4. Pelepah rebung hijau (6/10 5 GY), arah pertumbuhan searah jarum jam. Ruas batang berwarna kuning bergaris hijau (5/8 7.5 GY), permukaan ruas batang gundul mengkilat kecuali di sekitar buku batang berbulu kempa coklat (4/3 2.5 Y) jarang, panjang $\mathrm{x}$ diameter ruas batang $31 \mathrm{~cm} \times 5,32 \mathrm{~cm}$, pangkal batang bengkok. Pelepah batang mendelta, menyutera coklat kehitaman (3/2 2.5 Y), daun pelepah batang mendelta, bagian dalam daun pelepah batang berbulu kempa tebal dan membentuk pola garis vertikal sejajar, posisi daun pelepah batang tegak, tinggi cuping 1,50-2 cm dengan bulu kejur 1-1,50 cm; ligula berbulu kejur 0,20-0,30 cm pada tepinya. Percabangan satu cabang lebih besar dari cabang lainnya, berkas cabang tersusun atas 7 cabang. Pelepah daun berbulu kempa coklat (4/4 2.5 Y); cuping berbulu kejur; ligula berbulu kejur pada tepinya. Daun hijau (4/8 $5 \mathrm{GY}$ ), permukaan daun abaksial dan adaksial gundul, panjang x lebar helaian daun $27-29,70 \mathrm{~cm} \times 3,70-4 \mathrm{~cm}$, pangkal daun tumpul.

Distribusi: Kabupaten Lombok Utara, Kecamatan Gangga, Desa Genggelang, Dusun Gondang timuq.

Nama lokal: Aur kuning (Sasak Bayan). 


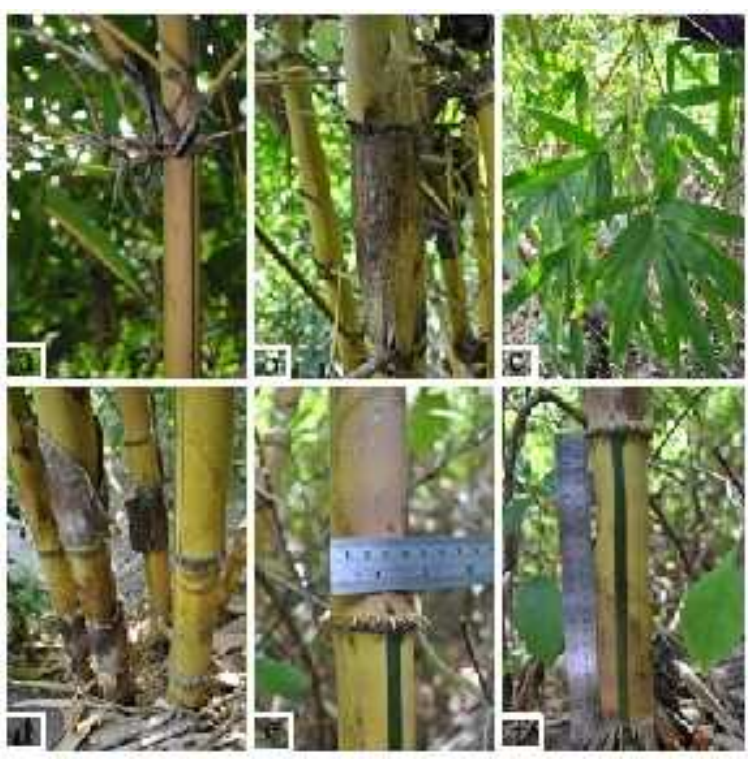

3.4 Peta Persebaran
Gambar 11. B. vulgaris var. vitata: (a). percabangan, (b). pelepah batang, (c). daun, (d). pangkal batang, (e). akar udara ruas ke4, (f). ruas batang 


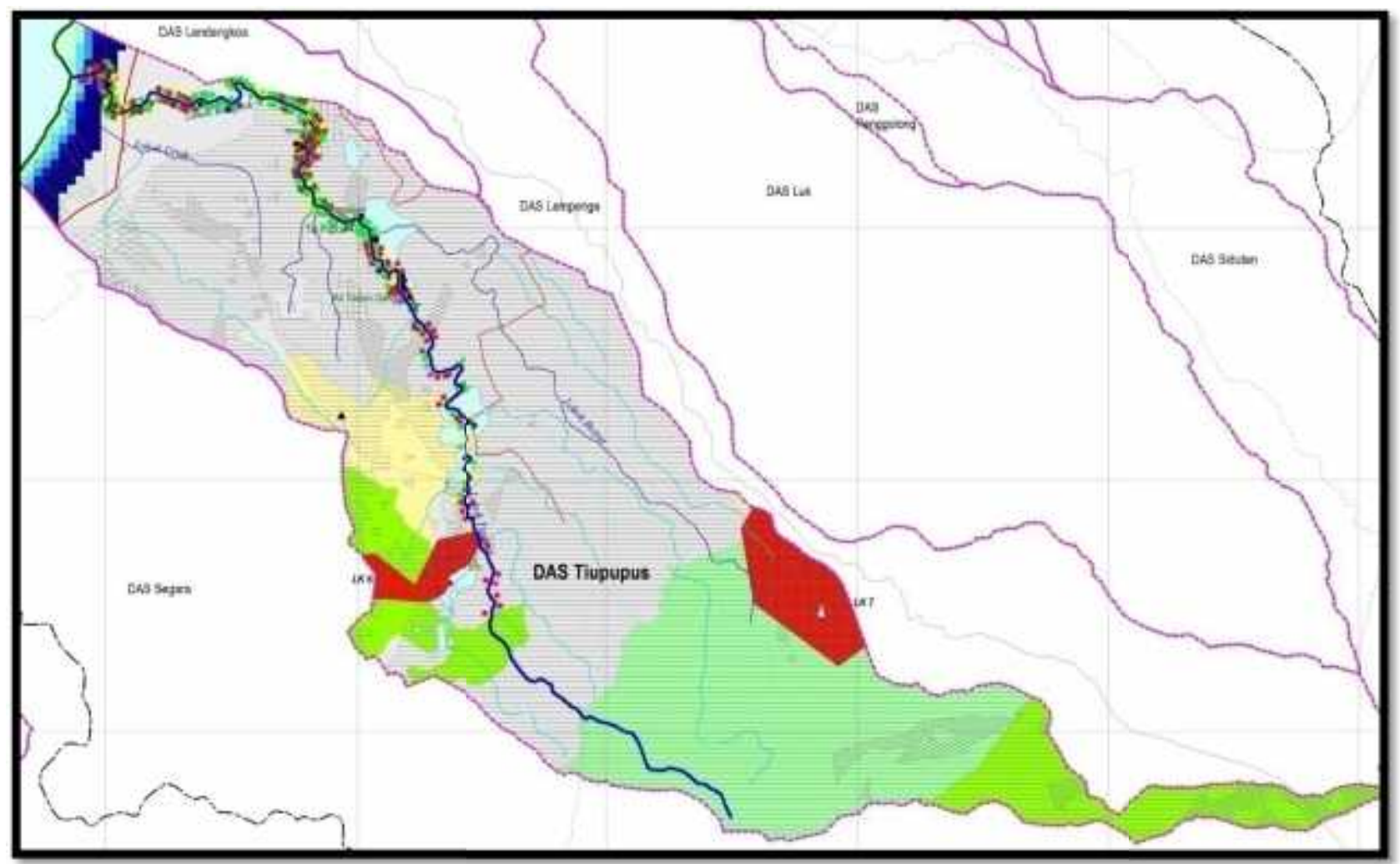

Gambar 12. Peta persebaran bambu di DAS Tiupupus Lombok Utara, ket: $\bigcirc$ B. vulgaris, $\bigcirc$ G. atter, ○ G. apus, $\bigcirc$ S. jaculans, ○ T. siamensis, ○ D. asper, $\bigcirc$ B. glaucophylla, ○B. multiplex, ○ B. maculata, ○ B. vulgaris var. vitata

Pada Gambar 12 di atas terlihat pola persebaran dari tiap-tiap jenis bambu yang ditemukan. Persebaran bambu di DAS Tiupupus di mulai dari ketinggian $11 \mathrm{mdpl}$ hingga 486 mdpl. Bambu yang ditemukan di seluruh ketinggian tempat (kosmopolitan) adalah B.vulgaris (11-484 mdpl) dan $D$. asper (19-486 mdpl). Bambu yang ditemukan di dataran rendah adalah $B$. vulgaris var. vitata (21 mdpl). Bambu yang ditemukan di dataran sedang adalah $S$. jaculans (23-188 mdpl) dan B. glaucophylla (90 mdpl). Bambu yang ditemukan di dataran cukup tinggi adalah $B$. multiplex (335 mdpl), dan bambu yang ditemukan di dataran rendah hingga ketinggian 300-an mdpl adalah B. maculata (20-340 mdpl), G. atter (13-351 mdpl), dan G. apus (15-398 mdpl).

\section{Kesimpulan}

Hasil penelitian ini didapatkan 9 jenis dan 1 varietas bambu yang termasuk ke dalam 5 genus di DAS Tiupupus Kabupaten Lombok Utara yaitu D. asper, T. siamensis, S. jaculans, G. atter, G. apus, B. glaucophylla, B. multiplex, $B$. maculata, $B$. vulgaris, dan B. vulgaris var. vittata. Bambu yang ditemukan di seluruh ketinggian tempat adalah B.vulgaris (11-484 mdpl) dan D. asper (19-486 mdpl), bambu yang ditemukan di dataran rendah adalah $B$. vulgaris var. vitata (21 mdpl), dan bambu yang ditemukan di dataran sedang adalah $S$. 
jaculans (23-188 mdpl) dan B. glaucophylla (90 mdpl).

\section{Daftar Pustaka}

Keng, H. 1969. Orders and Families of Malayan Seed Plants. University of Malaya Press. Kuala Lumpur.

Lawrence, G.H.M. 1951. Taxonomy of Vascular Plants. The Macmillan Company. New York.

Paembonan, A.R. 2014. Analisis Kemampuan Bambu Ater Gigantochloa atter (Hassk.) Kurz. dalam Mengabsorpsi Karbon Dioksida di Kecamatan Buntao' Rantebua Kabupaten Toraja Utara. Penelitian. Universitas Hasanuddin. Makassar.

Radford, A. E., et al. 1974. Vascular Plants Systematics. Harper \& Row, Publishers, Inc. New York.
Sjah, T., Markum dan S. Budhy. 2007. Studi Pengembangan Bambu di Pro-vinsi Nusa Tenggara Barat. PUSPECTRA UNRAM dan BPDAS DMS. Mataram.

Sokal, R.H and P.A. Sneath. 1963. Principle of Numerical Taxonomy. W.H. Freeman and Co. San Francisco. pp 291-303.

Sukawi. 2010. Bambu Sebagai Alternatif Bahan Bangunan dan Konstruksi di Daerah Rawan Gempa. TERAS. X(1): 1-10.

Widjaja, E.A. 2001. Identikit Jenis-jenis Bambu di Kepulauan Sunda Kecil. Puslitbang Biologi. LIPI. Bogor.

Widjaja dan Karsono. 2005. Keanekaragaman Bambu di Pulau Sumba. Biodiversitas. 6 (2): 95-99.

Wong, K.M. 2004. Bamboos The Amazing Grass. International Plant Generic Resources Institute (IPGRI) and University Malaya. Kuala Lumpur. 